\title{
АНАЛІЗ РИНКУ МАШИНОБУДУВАННЯ УКРАЇНИ: ПРОБЛЕМИ І ПЕРСПЕКТИВИ РОЗВИТКУ
}

DOI: $10.32620 /$ cher.2019.4.03

\begin{abstract}
Постановка проблеми. У світлі глобалізаційних процесів на сучасному етапі розвитку економіки України, перед вітчизняними підприємствами машинобудівної галузі постала проблема підвищення рівня їх конкурентоспроможності на світовому ринку, що у свою чергу сприяла активізації їх інноваційної діяльності. Необхідність у впровадженні заходів, щодо підвищення рівня інвестиційної привабливості українських підприємств, обумовлюють доцільність проведення аналізу сучасного стану підприємств машинобудівної галузі. Метою статті є визначення ролі машинобудівної галузі виробництва в загальному промисловому комплексі, дослідження стану, проблем та визначення пріоритетів подальшого розвитку машинобудування України з урахуванням вимог сучасного ринку. Об'єкт дослідження - машинобудівна галузь України, її стан в умовах світової глобалізації. Методи, використані в досліджені. Методи дослідження, що використовуються в процесі написання статті, передбачають застосування загальнонаукових та емпіричних підходів до економічної науки, заснованих на систематичному підході. Використання діалектичного методу дало можливість виділити особливості сучасних інноваційних процесів, а також дослідити проблеми створення інвестиційно-привабливого середовища в машинобудівній галузі України. Історичний метод застосовано при вивченні історичного досвіду хронології подій і фактів в розвитку економіки України. Для одержання дослідницьких висновків використано також загальнонаукові системний та логічний методи. Інформаційну базу наукового дослідження склали монографії, наукові статті вітчизняних та закордонних науковців, правові акти що регулюють діяльність підприємства та дані Державної служби статистики України. Гіпотеза дослідження. Проведення постійного моніторингу сучасного стану машинобудування України та впровадження результатів його аналізу на практиці, призведе до поліпшення інвестиційної привабливості галузі. Виклад основного матеріалу. У науковій статті досліджено роль машинобудування як провідної галузі економіки України. На основі статистичних даних проаналізовано динаміку основних показників розвитку машинобудівної галузі України за 2010 2018 рр. Виділено значні проблеми досліджуваної галузі, визначено пріоритети їі подальшого розвитку. Оригінальність та практичне значення дослідження полягає в поглибленні обгрунтування основних проблем інвестиційної привабливості машинобудівної галузі. Практичне значення проведеного дослідження полягає в тому, що основні його положення можуть виступати науковим підгрунтям розвитку машинобудівних підприємств, в розрізі дослідження проблем підвищення інвестиційної привабливості галузі. Висновки дослідження. Так як машинобудування - це одна 3 провідних галузей промисловості, то воно виступає показником технічного рівня країни. Нестача фінансових ресурсів у підприємств, через яку дуже повільно вирішуються проблеми відновлення виробничого потенціалу галузі, призводять до гальмування загального розвитку машинобудування України. За результатами проведеного дослідження можна стверджувати, що основним дестимулятором реалізації потенціалу галузі виступає відсутність матеріальної бази. А отже, розв'язання проблем підвищення інвестиційної привабливості галузі, забезпечить подальший розвиток машинобудівного комплексу України.
\end{abstract}

\section{Ключові слова:}

світова глобалізація, інвестиційна привабливість, активізація, машинобудівна галузь, потенціал.

${ }^{1}$ Кракос Юлія Борисівна, канд. екон. наук, доцент кафедри «Фінанси», Національний аерокосмічний університет ім. М.Є. Жуковського «Харківський авіаційний інститут», м. Харків, Україна.

Krakos Julia, Ph.D. in Economic, Associate Professor of Finances Department National Aerospace University «Kharkiv Aviation Institute», Kharkiv, Ukraine.

ORCID ID: 0000-0001-8058-6336

e-mail: july.krakos@gmail.com

2 Приходько Аліна Олександрівна, магістрант спеціальності «Фінанси, банківська справа та страхування», Національний аерокосмічний університет ім. М.С. Жуковського «Харківський авіаційний інститут», м. Харків, Україна.

Prikhodko Alina, Master's degree of Finance, Banking and Insurance Specialty National Aerospace University «Kharkiv Aviation Institute», Kharkiv, Ukraine.

ORCID ID: 0000-0003-1109-0542

e-mail: aprikhodko96@gmail.com 


\section{MECHANICAL ENGINEERING MARKET ANALYSIS: PROBLEMS AND PROSPECTS OF DEVELOPMENT}

Problem statement. In the light of globalization processes at the present stage of development of the Ukrainian economy, domestic enterprises of the machine-building industry faced the problem of increasing their competitiveness in the world market, which in turn contributed to the Activation of their innovative activities. The need of implement measures to increase the level of investment attractiveness of Ukrainian enterprises, determines the feasibility of the analysis of the current state of the machine-building industry. The aim of study is to investigate the role of machine-building industry production in total industrial complex, the research status, the challenges and to identify priorities for further development of engineering in Ukraine that are taking into account the requirements of the Modern market. Research object. The object of the research is the machinebuilding industry of Ukraine and its condition in the conditions of world globalization. Methods. Research methods that were used in the process of writing the article - providing for the application of General scientific and empirical approaches to economic science - were based on a systematic approach. The appliance of the dialectical method allows us to highlight the features of modern innovation processes, furthermore, to explore the problems of creating an investment-attractive environment in the machine-building industry of Ukraine. The traditional method is applied in the study of previous experience chronology of events and facts in the development of the economy of Ukraine. General scientific systematical and logical methods were also used to obtain research conclusions. The basis of the information in this paper is on the researches consisted of monographs, scientific articles of domestic, foreign articles, legal activities of the enterprises and data of the State Statistics Service of Ukraine. The hypothesis of the study. Continuous monitoring of the current state of machine building in Ukraine and implementation of the results of its practical analysis will improve the investment attractiveness of the industry. Presentation of the main material. In this scientific article the role of mechanical Engineering as the leading industry of economy of Ukraine is investigated. Based on statistical data, the dynamics of the main indicators of development of the machine-building industry of Ukraine for 2010-2018 was analyzed. Significant problems of the studied area are Identified, priorities for further development are determined. The originality and practical significance of this study is to investigate deeply the main problems of investment attractiveness of the engineering industry. also this study's main provisions can serve as a scientific basis for the development of machine-building enterprises, in the context of the study of the problems of increasing the investment attractiveness of the industry. Conclusions of the study. Since Mechanical Engineering is one of the leading industries, it is an indicator of the technical level of the country. Lack of financial resources at the enterprises through problems such as low speed potential restoration of production in industry were solved. This leaded to braking of the General development of mechanical engineering of Ukraine. In challenging situations of financial and economic activity, the enterprises of the machine-building industry need support from the State, in particular that needs a part of tax incentives for large-scale projects to modernize production facilities and Provide domestic producers with state orders. According to the results of the conducted research it can be argued that the main stimulus for the realization of the industry's potential is the lack of material resources. Therefore, the solution for problems of increasing the investment attractiveness of industry will insure the further development of machine-building complex of Ukraine.

Key words:

world globalization, investment attractiveness, revitalization, machine-building industry, potential.

\section{АНАЛИЗ РЫНКА МАШИНОСТРОЕНИЯ УКРАИНЫ: ПРОБЛЕМЫ И ПЕРСПЕКТИВЫ РАЗВИТИЯ}

Постановка проблемы. В свете глобализационных процессов на современном этапе развития экономики Украины, перед отечественными предприятиями машиностроительной отрасли возникла проблема повышения уровня их конкурентоспособности на мировом рынке, что в свою очередь способствовало активизации их инновационной деятельности. Необходимость во внедрении мероприятий по повышению уровня инвестиционной привлекательности украинских предприятий, обуславливают целесообразность проведения анализа современного состояния предприятий машиностроительной отрасли. Целью статьи является определение роли машиностроительной отрасли производства в общем промышленном комплексе, исследование состояния, проблем и определение приоритетов дальнейшего развития машиностроения Украины с учетом требований современного рынка. Объект исследования - машиностроительная отрасль Украины, ее состояние в условиях мировой глобализации. Meтоды, использованные в исследовании. Методы исследования, используемые в процессе написания статьи, предусматривающие применение общенаучных и эмпирических подходов к экономической науке, основанных на систематическом подходе. Использование диалектического метода позволило выделить особенности современных инновационных процессов, а также исследовать проблемы создания инвестиционно-привлекательной среды в машиностроительной отрасли Украины. Исторический метод применен при изучении исторического опыта хронологии событий и фактов в развитии экономики Украины. Для получения исследова- 
тельских выводов использовано также общенаучные системный и логический методы. Информационную базу научного исследования составили монографии, научные статьи отечественных и зарубежных ученых, правовые акты регулирующие деятельность предприятия и данные Государственной службы статистики Украины. Гипотеза исследования. Проведение постоянного мониторинга современного состояния машиностроения Украины и внедрение результатов его анализа на практике приведет к улучшению инвестиционной привлекательности отрасли. Изложение основного материала. В научной статье исследована роль машиностроения как ведущей отрасли экономики Украины. На основе статистических данных проанализирована динамика основных показателей развития машиностроительной отрасли Украины за 2010-2018 гг. Выделены значительные проблемы исследуемой области, определены приоритеты дальнейшего развития. Оригинальность и практическая значимость исследования заключается в углублении обоснование основных проблем инвестиционной привлекательности машиностроительной отрасли. Практическое значение проведенного исследования заключается в том, что основные его положения могут выступать научным основой развития машиностроительных предприятий, в разрезе исследования проблем повышения инвестиционной привлекательности отрасли. Bblводы исследования. Так как машиностроение - это одна из ведущих отраслей промышленности, то оно выступает показателем технического уровня страны. Недостаток финансовых ресурсов у предприятий, через которую очень медленно решаются проблемы восстановления производственного потенциала отрасли, приводят к торможению общего развития машиностроения Украины. В составленных, тяжелых условиях ведения финансово хозяйственной деятельности, предприятия машиностроительной отрасли нуждаются в поддержке со стороны государства, в частности во внедрении налоговых льгот на проведение масштабных проектов по модернизации производственных мощностей и обеспечении отечественных производителей государственными заказами. По результатам проведенного исследования можно утверждать, что основным дестимулятором реализации потенциала отрасли выступает отсутствие материальной базы. Следовательно, решение проблем повышения инвестиционной привлекательности отрасли, обеспечит дальнейшее развитие машиностроительного комплекса Украины.

\section{Ключевые слова:}

мировая глобализация, инвестиционная привлекательность, активизация, машиностроительная отрасль, потенциал.

Постановка проблеми. В ході трансформаційних процесів в економічній системі України, які супроводжуються спрямованістю до набуття більшої економічної та адміністративної стабільності на шляху до євроінтеграції, перед підприємствами машинобудівної галузі України постає важлива проблема не тільки підвищення рівня їх конкурентоспроможності на світовому ринку, але й пошуку додаткових фінансових та матеріальних ресурсів, що визначає актуальність даного дослідження. Процес адаптації українських виробників до «європейських стандартів» ускладняється неможливістю швидкої відмови від так званих «пережитків минулого»базових технологій та устаткування, які «достались» їм з часів СРСР. Пошук виходу із такого «скрутного» становища, обумовлює доцільність проведення аналізу сучасного стану підприємств машинобудівної галузі.

Аналіз останніх джерел та публікацій. Проблемами функціонування машинобудування в Україні займалися відомі вченіекономісти: Н. Г. Чумаченко, Б. Н. Крижанівський, I. С. Калиниченко, Н. Т. Пашута, В. I. Ольшевський та інші. Але, враховуючи постійні динамічні зміни у машинобудівному комплексі та виникнення нових проблем його функціонування, залишається невирішеним питання аналізу сучасного стану машинобудівного комплексу України.

Метою статті є визначення ролі машинобудівної галузі виробництва 3 загальному промисловому комплексі України та аналіз сучасного стану машинобудування України, виявлення основних проблем та визначення пріоритетів подальшого розвитку.

Виклад основного матеріалу дослідження. Сьогодні провідну роль у забезпеченні зростання економіки країни відіграє промисловість. Промислове виробництво України $\epsilon$ базою для створення науковотехнічного, економічного й соціального прогресу. Вітчизняне машинобудування - одна із складових галузей промисловості і фундамент економічного потенціалу країни.

Розвиток машинобудування $є$ показником технічного рівня країни. Йому належить ключова роль у забезпеченні конкурентоспроможності продукції вітчизняних товаровиробників на внутрішньому і зовнішньому ринках. Перш за все, машинобудування - це сукупність галузей промисловості, які виробляють машини та обладнання для всіх ланок народного господарства [6]. Важке машинобудування забезпечує різноманітним обладнанням енергетику, металургійну, хімічну, 
гірничодобувну та будівельну промисловість. В сучасних умовах йому належить виключно важлива роль у прискоренні науковотехнічного прогресу. Випускаючи засоби виробництва для різних галузей господарства, машинобудування забезпечує комплексну

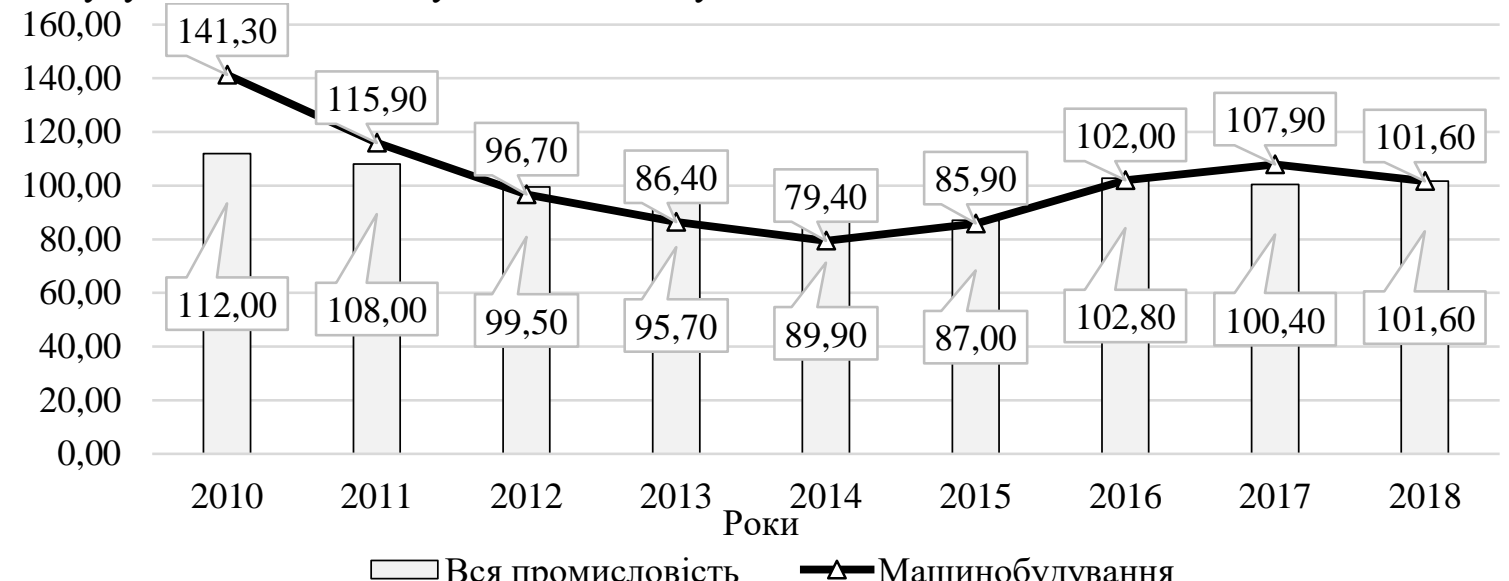

Рисунок 1 - Індекси промислової продукції та продукції машинобудівної галузі України Джерело: узагальнено авторами на підставі [1]

Така ситуація свідчить про те, що інвестування в машинобудівний комплекс може бути вигідним, оскільки його продукція має попит серед українських споживачів, а потенціал галузі є досить високим. Серед об'єктивних причин спаду - зниження економічної та інвестиційної активності на внутрішньому ринку. Проведений аналіз джерел фінансування даної галузі показав, що найбільш значущим джерелом фінансового забезпечення машинобудівних підприємств України на сьогодні є державні інвестиції, але особливу увагу слід приділити проблемі залучення іноземних інвестицій які не тільки сприяють стабілізації макроекономіки країни, але й сприяють зростанню промисловості та забезпечують доступ до інноваційних технологій.

Прогрес машинобудівної галузі неможливий без значних інвестицій. На сьогодні, велика частина вітчизняних підприємств змушена використовувати в своїй діяльності обладнання, знос якого знаходиться на критично допустиму рівні. Причиною цьому $\epsilon$ нестача фінансових ресурсів, через яку дуже повільно вирішуються проблеми відновлення виробничого потенціалу галузі. Як результат, відбувається гальмування загального розвитку машинобудування країни, в основі якого лежать вітчизняні наукові розробки та інноваційні технології, що в свою чергу, призводить до втрати рівня забезпечення конкурен- механізацію та автоматизацію виробництва.

Протягом дев'яти років спостерігається високий ступінь кореляції між індексами промислової продукції і індексами продукції машинобудування (рис. 1). тоспроможності кінцевої продукції машинобудівної галузі України.

Обсяги капітальних інвестицій у промисловість та виробництво машин та устаткування України за 2010 - 2018 роки представлені на рис. 2.

Як бачимо, за останні роки прослідковується стабільна позитивна динаміка зросту обсягів капітальних інвестицій, відбувається це в основному користуючись власними коштами підприємств та організацій, що у свою чергу вимощує «ковзке» підгрунтя для формування інвестиційно привабливої загальної промисловості України. Причина, перш за все в обмеженні власних коштів підприємств їхніми прибутками, адже потреби в інвестиціях, в разі реалізації інвестиційного проекту, в короткостроковій перспективі завжди значно більше, ніж поточні доходи. Тому підприємства зазвичай залучають кошти 3 різних джерел, як правило - не дешевих, - виключенням стають державні інвестиції.

В складений період «відлиги» від недавньої економічної кризи, яка поглибилася в Україні через події 2013 - 2014 років, подальший розвиток машинобудівної галузі України, забезпечить саме стимулювання виробництва зі сторони держави.

У табл. 1 наведено статистику макроекономічних показників за період 2010 - 2018 роки. 


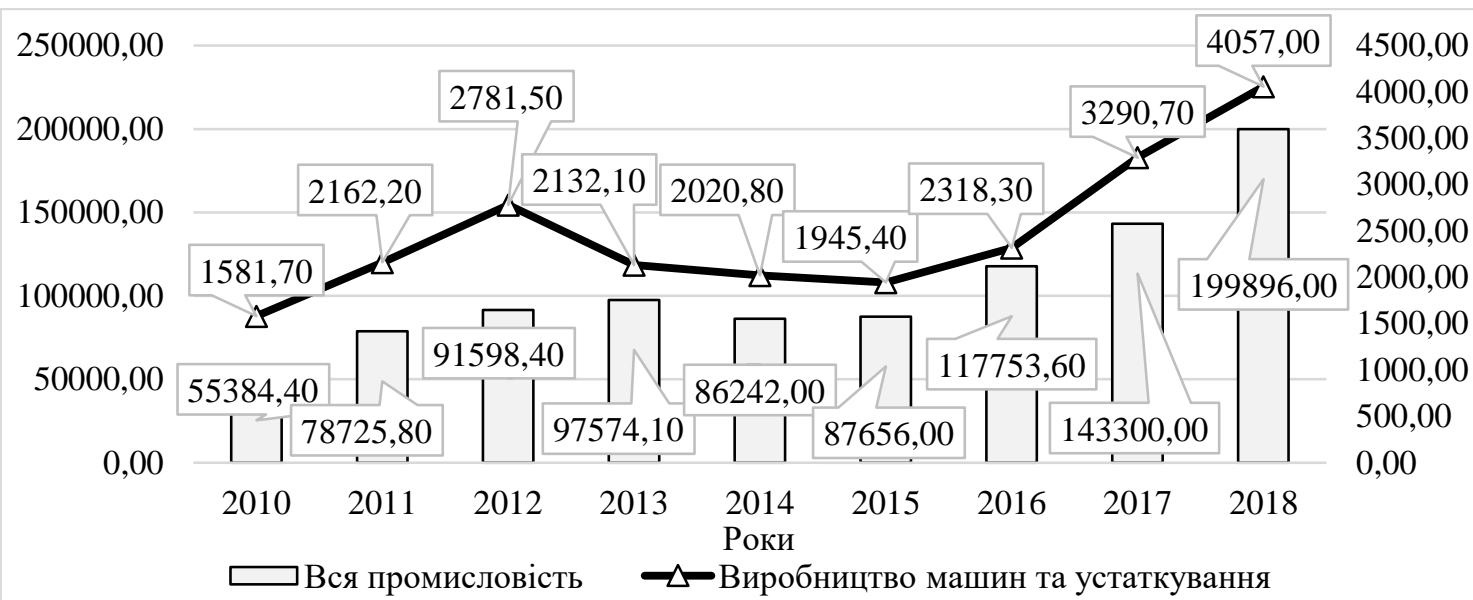

Рисунок 2 - Обсяги капітальних інвестицій у виробництво машин та устаткування України, млн. грн Джерело: узагальнено авторами на підставі [1]

\section{Динаміка основних макроекономічних показників України за період 2010 - 2018 роки}

Т а б ли ц я 1

\begin{tabular}{|c|c|c|c|c|c|c|c|c|c|c|}
\hline \multirow{2}{*}{ Показник } & \multirow{2}{*}{$\begin{array}{c}\text { Одини- } \\
\text { ця ви- } \\
\text { міру }\end{array}$} & \multicolumn{9}{|c|}{ Роки } \\
\hline & & 2010 & 2011 & 2012 & 2013 & 2014 & 2015 & 2016 & 2017 & 2018 \\
\hline \multirow{2}{*}{$\begin{array}{l}\text { Валовий } \\
\text { внутріш- } \\
\text { ній про- } \\
\text { дукт } \\
\text { (ВВП) }\end{array}$} & $\begin{array}{c}\text { млн. } \\
\text { грн } \\
\end{array}$ & 1082569 & 1316600 & 1408889 & 1454931 & 1566728 & 1979458 & 2383182 & 2982920 & 3558706 \\
\hline & $\begin{array}{l}\text { млн. } \\
\text { USD }\end{array}$ & 136419,0 & 163160,0 & 175781,0 & 183310,0 & 131805,0 & 90615,0 & 93270,0 & 112154,0 & 130832,0 \\
\hline $\begin{array}{l}\text { Валовий } \\
\text { зовніш- } \\
\text { ній борг } \\
\text { (ВЗБ) }\end{array}$ & $\begin{array}{l}\text { млн. } \\
\text { USD }\end{array}$ & 117343,0 & 126236,0 & 135065,0 & 142079,0 & 126308,0 & 118729,0 & 113518,0 & 116578,0 & 114710,0 \\
\hline ВЗБ/ВВП & $\%$ & 86,02 & 77,37 & 76,84 & 77,51 & 95,83 & 131,03 & 121,71 & 103,94 & 87,68 \\
\hline $\begin{array}{l}\text { Індекс } \\
\text { інфляцї }\end{array}$ & $\%$ & 109,10 & 104,60 & 99,80 & 100,50 & 124,90 & 143,30 & 112,40 & 113,70 & 109,80 \\
\hline \multirow{2}{*}{$\begin{array}{l}\text { Доходи } \\
\text { бюджету }\end{array}$} & $\begin{array}{c}\text { млн. } \\
\text { грн }\end{array}$ & 240615,2 & 314616,9 & 346054,0 & 339180,3 & 357084,2 & 534694,8 & 616274,8 & 793265,0 & 928108,3 \\
\hline & $\begin{array}{l}\% \text { от } \\
\text { ВВП }\end{array}$ & 22,23 & 23,90 & 24,56 & 23,31 & 22,79 & 27,01 & 25,86 & 26,59 & 26,08 \\
\hline \multirow{2}{*}{$\begin{array}{l}\text { Видатки } \\
\text { бюджету }\end{array}$} & $\begin{array}{c}\text { млн. } \\
\text { грн }\end{array}$ & 303588,7 & 333459,5 & 395681,5 & 403403,2 & 430217,8 & 576911,4 & 684743,4 & 839243,7 & 985842,0 \\
\hline & $\begin{array}{l}\% \text { от } \\
\text { ВВП }\end{array}$ & 28,04 & 25,33 & 28,08 & 27,73 & 27,46 & 29,14 & 28,73 & 28,13 & 27,70 \\
\hline $\begin{array}{l}\text { Золото- } \\
\text { валютні } \\
\text { резерви }\end{array}$ & $\begin{array}{l}\text { млн. } \\
\text { USD }\end{array}$ & 34576,0 & 31794,6 & 24546,1 & 20415,7 & 7533,3 & 13299,9 & 15539,3 & 18808,4 & 20820,4 \\
\hline $\begin{array}{l}\text { Облікова } \\
\text { ставка } \\
\text { НБУ } \\
\end{array}$ & $\%$ & 7,75 & 7,75 & 7,56 & 6,50 & 14,00 & 22,00 & 14,00 & 14,50 & 18,00 \\
\hline $\begin{array}{l}\text { Населення } \\
\text { України }\end{array}$ & $\begin{array}{l}\text { тис. } \\
\text { осіб }\end{array}$ & 45962,9 & 45778,5 & 45633,6 & 45553,0 & 45426,2 & 42928,9 & 42760,5 & 42584,5 & 42386,4 \\
\hline $\begin{array}{l}\text { Рівень } \\
\text { безробіття }\end{array}$ & $\%$ & 8,80 & 8,60 & 8,10 & 7,70 & 9,70 & 9,50 & 9,70 & 9,90 & 9,10 \\
\hline $\begin{array}{l}\text { Мініма- } \\
\text { льна } \\
\text { заробітна } \\
\text { плата } \\
\end{array}$ & грн & 888,25 & 963,08 & 1098,08 & 1152,92 & 1218,00 & 1271,33 & 1438,50 & 3200,00 & 3723,00 \\
\hline $\begin{array}{l}\text { Прожит- } \\
\text { ковий } \\
\text { мінімум }\end{array}$ & грн & 843,17 & 914,08 & 1042,42 & 1113,67 & 1176,00 & 1227,33 & 1388,08 & 1603,67 & 1744,83 \\
\hline
\end{tabular}


Зростання ВВП у 2018 році було сформоване внаслідок:

- внутрішніх запозичень (вплинули на збільшення ВВП через зростання обсягу доходів банківського сектора та фінансування бюджетних програм);

- зовнішніх запозичень;

- інфляційних чинників зростання товарообігу; ність) [5].

- зростання АПК (хороша врожай-

Нинішне зниження темпів інфляції пов'язано передусім із проведенням Національним банком України жорсткої монетарної політики, що водночас стримує економічне зростання. Як можна бачити, на фоні росту видатків бюджету, скорочення економічно активного населення, зростає сума державного боргу на душу населення. Збільшення обсягу золотовалютних резервів, більшою мірою, відбулося завдяки зростанню попиту іноземців на облігації України. Також надходженню валюти в міжнародні резерви сприяла сприятлива ситуація на світових ринках і високі ціни на товари, які Україна експортує.

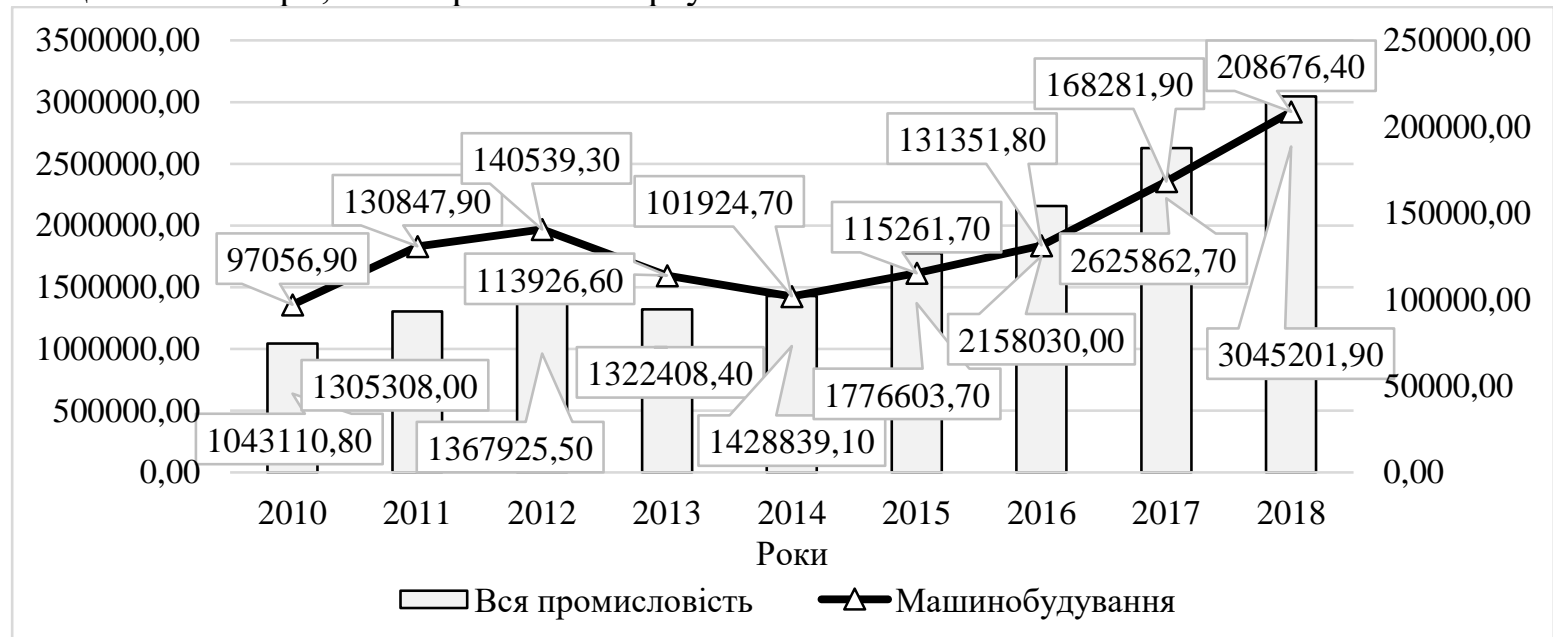

Рисунок 3 - Обсяги реалізованої продукції машинобудівної галузі, млн. грн Джерело: узагальнено авторами на підставі [1]

Сучасне становище ринкової економіки диктує жорсткі правила конкурентної боротьби за місце підприємств на світовій арені. В складених тяжких реаліях ведення бізнесу, найбільш конкурентоспроможними, на сьогодні є не окремі суб'єкти господарювання, а їх об'єднання або групи підприємств. Це пояснюється тим, що для забезпечення та реалізації безперебійного виробничого процесу, дані структури здатні на прийняття необхідних управлінських рішень та на їх адаптацію щодо змін, які відбуваються в економіці в
Мінімальна заробітна плата і прожитковий мінімум продовжують динаміку зросту.На даний час необхідність у впровадженні податкових пільг на проведення масштабних проектів 3 модернізації виробничих потужностей та забезпечення вітчизняних виробників державними замовленнями, у тому числі й на інноваційну продукцію - основні дестимулятори прогресу даної галузі виробництва [2].

Обсяги реалізованої продукції машинобудівної галузі та загальної промисловості України за 2010 - 2018 роки відображені на рис. 3.

Поліпшення динаміки стрімкого росту обсягів реалізованої продукції машинобудівної галузі, в першу чергу пов'язано зі специфікою даної галузі. Після всіх економічних, а в першу чергу політичних, в Україні настає процес активної відбудови всіх економічно важливих галузей народного господарства. Інструментом при цьому постає саме машинобудівна галузь, яка виступає сполучною ланкою між усіма економічними суб'єктами. найкоротші терміни, що значною мірою впливає на їх конкурентні переваги перед окремими суб'єктами господарювання. Цілі, переслідувані такими процесами саме вітчизняних об'єднань носять різні характери: від збереження фінансової стабільності до мінімізації виробничих витрат, але спільною рисою залишається так звана - «спроба вижити» в складених умовах зовнішнього середовища підприємства.

За даними Державної служби статистики України, на сьогодні, динаміка зростання 
загальної кількості суб'єктів господарювання поступово починає вирівнюватись, що пояснюється найскладнішими умовами входу підприємств на ринок вітчизняної продукції. Сучасний розвиток економіки поступово витісняє процес вільної конкуренції, не даючи змоги окремим економічним суб'єктам про- тистояти результативній стадії росту великої кількості підприємств - монополізації. Відбиття процесу переходу від вільної конкуренції до процесу монополізації, в розрізі дослідження машинобудівної галузі України, зображено на рис. 4.

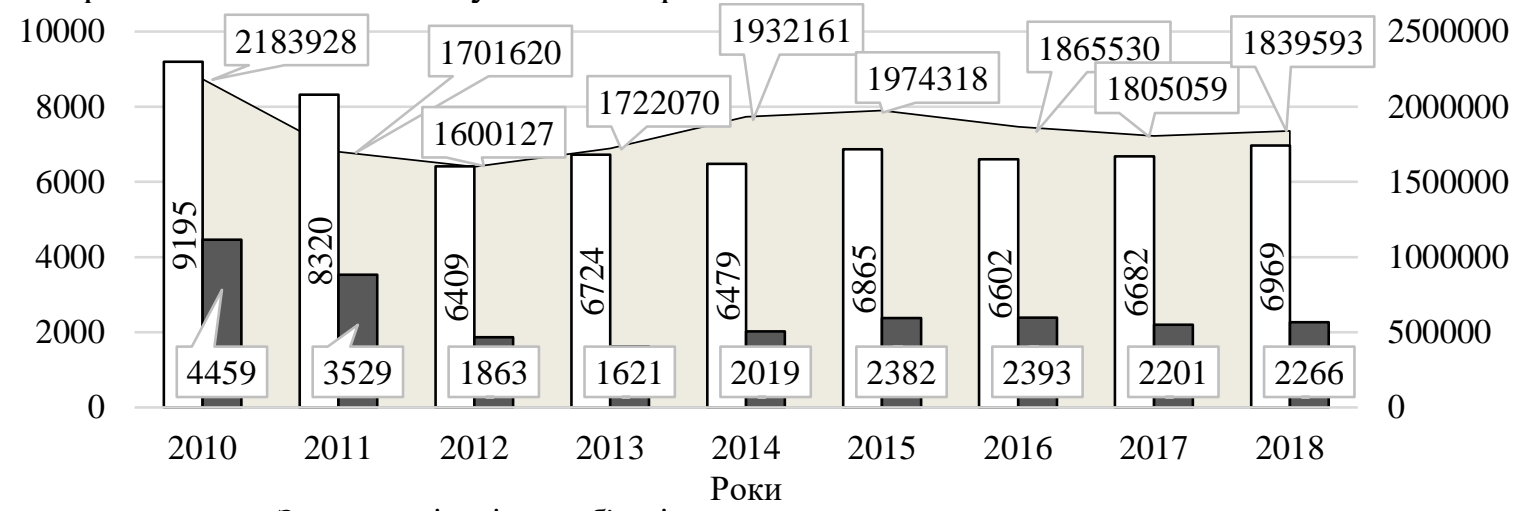

$\square$ Загальна кількість суб'єктів господарювання

口Загальна кількість суб'єктів господарювання машинобудівної галузі

口Кількість фізичних осіб-підприємців машинобудівної галузі

Рисунок 4 - Статистична інформація щодо загальної кількості суб' єктів господарювання машинобудівної галузі України

Джсерело: узагальнено авторами на підставі [1]

Як бачимо, досягнута «стадія зрілості» динаміки зросту загальної кількості суб'єктів господарювання України, призвела до посилення конкуренції між великими гравцями ринку, про що свідчать зрослі темпи зростання загальної кількості підприємств машинобудівної галузі. Стабільність даної галузі виробництва значною мірою внаслідок історично великих обсягів поставок і довгострокових відносин з країнами-партнерами. Вдовольнити нарощувані потреби таких клієнтів, як показує практика, в змозі лише великі підприємства, що відтісняє «маленьких гравців» на ще дальню дистанцію.

Основним ризиком для машинобудівної галузі України виступає зниження попиту на вітчизняну продукцію призначену для експорту в такі країни, разом з тим головною перспективою постає налагодження постачань нашої продукції в країни Азії та Європи, 3 огляду на розвиток китайської економіки, як головного інноваційного діяча для багатьох країн світу. Варто зазначити, що в умовах світової глобалізації, спрямованість стратегій розвитку більшості високотехнологічних виробництв України, зокрема підприємств машинобудівної галузі, до отримання конкурентних переваг, перш за все, на міжнародному ринку, майже повністю спростовує доцільність створення потужного виробництва орі- єнтуючись лише на попит внутрішнього ринку.

Висновки та перспективи подальших досліджень. Таким чином, можна стверджувати, що основними завданнями на сучасному етапі розвитку машинобудівної галузі України $\epsilon$ підвищення іï конкурентоспроможності (як на внутрішньому ринку, так і на світовій арені) та поліпшення інвестиційної привабливості галузі. Проведене дослідження показало, що наявна структура інвестування в загальну промисловість, та в іiі розрізі - в машинобудівну галузь України, наразі лише гальмує інвестиційні перспективи підприємств і свідчить про неефективну державну політику. Як результат - відсутність у потенційних інвесторів реальних стимулів для акумулювання та інвестування власних коштів в основний капітал підприємств. 3 огляду на глобалізаційні процеси в економіці, активізація інноваційної діяльності машинобудівних підприємств України сьогодні, постає питанням не лише їхього розвитку та конкурентоспроможності, а й в можливості існування в майбутньому [4]. Наразі в складених, важких умовах ведення фінансовогосподарської діяльності підприємства машинобудівної галузі потребують в підтримці з боку держави. Вирішення потреби в податкових пільгах, особливо питання стосується 
відшкодування ПДВ, адже характерною особливістю галузі є тривалий виробничий цикл, а при отриманні передоплати держава відразу вилучає з обігу 20\% від нього у вигляді ПДВ, в значній мірі вплине на дефіцит оборотних коштів підприємств.

Отже, провівши аналіз сучасного стану машинобудівної галузі України, можна стверджувати про наявність умов для розвитку машинобудівного комплексу, однак через відсутність матеріальної бази країна не здатна повністю реалізувати свій потенціал.

\section{Література}

1. Офіційний сайт Державної служби статистики України. URL : http://www.ukrstat.gov.ua (дата звернення: 19.11.2019).

2. Машиностроение Украины: текущие тенденции URL: https://www.minprom.ua/news/755.html (дата звернення: 18.11.2019)

3. Король К. В. Економічний стан та проблеми розвитку галузі машинобудування в Україні. Економічний вісник Донбасу. 2014. № 1(35). C. 157-162.

4. Скиба Г. В. Механізми та методи державної підтримки інноваційної діяльності підприємств України з урахуванням іноземного досвіду. Вісник Хмельницького національного університету. 2010. № 6. С. 56-58.

5. Глобальний аналіз базових макроекономічних показників України (2013-2018 pp.). URL: http://publicaudit.com.ua/reports-onaudit/globalnyj-analiz-bazovyhmakroekonomichnyh-pokaznykiv-ukrayiny-

Стаття надійшла

до редакції : 30.11.2019 p. 2013-2018-rr/ (дата звернення: 19.11.2019)

6. Меленчук Ю. Сучасний стан та тенденції розвитку машинобудівної галузі України. Галицький економічний вісник. 2014. Том 47. № 4. С. 28-34.

\section{References}

1. Official site of the State Statistics Service of Ukraine. Retrieved from: http://www.ukrstat.gov.ua (accessed: 11/19/2019).

2. Engineering of Ukraine: current trends Retrieved from: https://www.minprom.ua/news/755.html (accessed: 11/18/2019)

3. Korol, K. V. (2014). Economic status and problems of development of machinebuilding industry in Ukraine. Economic Bulletin of Donbass, 1(35), 157-162.

4. Skiba, G. V. (2010). Mechanisms and methods of state support of innovative activity of Ukrainian enterprises taking into account foreign experience. Bulletin of Khmelnitsky National University, 6, 56-58.

5. Global analysis of basic macroeconomic indicators of Ukraine (2013-2018). Retrieved from: http://publicaudit.com.ua/reports-onaudit/globalnyj-analiz-bazovyh-

makroekonomichnyh-pokaznykiv-ukrayiny2013-2018-rr/ (accessed: 11/19/2019)

6. Melenchuk, $Y$. (2014). The current state and tendencies of development of machinebuilding industry of Ukraine. Galician Economic Bulletin, Vol. 47, 4, 28-34.

Стаття прийнята

до друку: 27.12.2019 p.

\section{Бібліографічний опис для цитування :}

Кракос Ю. Б. Аналіз ринку машинобудування україни: проблеми і перспективи розвитку / Ю. Б. Кракос, А. О. Приходько // Часопис економічних реформ. - 2019. № 4 (36). - C. 21-28. 